\title{
Pengaruh Pembelajaran Menggunakan Media Pembelajaran Interaktif terhadap Hasil Belajar Siswa di Sekolah Dasar
}

\author{
Udi Budi Harsiwi ${ }^{1}$, Liss Dyah Dewi Arini ${ }^{2}$ \\ Prodi D3 RMIK, Fakultas Ilmu Kesehatan, Universitas Duta Bangsa Surakarta, Indonesia ${ }^{1,2}$ \\ E-mail : Udi budi@udb.ac.id $\underline{\text { liss dyah@udb.ac.id }}$
}

\begin{abstract}
Abstrak
Salah satu faktor yang mempengaruhi kemajuan bangsa adalah kualitas sumber daya manusia dalam menguasai pengetahuan dan teknologi di era revolusi industri 4.0. Kualitas pendidikan semakin dituntut untuk meningkat agar dapat mengikuti perkembangan zaman yang berkembang dengan sangat pesat. Media pembelajaran juga merupakan dasar yang sangat diperlukan demi berhasilnya proses pembelajaran. Tujuan penelitian ini adalah (1) mengembangkan media pembelajaran berbasis Adobe Flash; (2) menganalisis perbedaan motivasi antara siswa yang menggunakan media Adobe Flash dan konvensional; (3) menganalisis perbedaan hasil belajar antara siswa yang menggunakan media Adobe Flash dan konvensional; (4) menganalisis perbedaan motivasi dan hasil belajar antara siswa yang belajar IPA menggunakan media Adobe Flash dan konvensional di SD N 06 dan 07 Ngringo, Karanganyar. Tahapan metode penelitian ini adalah penelitian eksperimen dengan rancangan postest only control group design. Subjek penelitian ini adalah siswa kelas V di SDN 06 dan 07 Ngringo, Karanganyar. Pengambilan kelas penelitian melalui teknik random sampling. Kegiatan dalam analisis data meliputi pengolahan data dan analisis statistik. Kesimpulan penelitian ini adalah secara umum model pembelajaran melalui media pembelajaran interaktif (video swf) dapat memotivasi siswa sehingga dapat meningkatkan prestasi belajar mahasiswa. Siswa memberikan respon positif terhadap implementasi model pembelajaran interaktif (video swf).
\end{abstract}

Kata kunci : pembelajaran interaktif, sistem peredaran darah, Adobe Flash, motivasi, hasil belajar

\begin{abstract}
One of the factors that influence the progress of the nation is the quality of human resources in mastering knowledge and technology in the era of the industrial revolution 4.0. The quality of education is increasingly required to improve in order to keep abreast of the times that are developing very rapidly. Learning media is also an indispensable basis for a successful learning process. The objectives of this study are (1) developing adobe flash-based learning media; (2) analyze the differences in motivation between students who use Adobe Flash and conventional media; (3) analyze differences in learning outcomes between students who use Adobe Flash and conventional media; (4) analyze differences in motivation and learning outcomes between students learning science using Adobe Flash and conventional media at SD N 06 and 07 Ngringo, Karanganyar. The stages of this research method are experimental research with posttest only control group design. The subjects of this study were fifth grade students at SDN 06 and 07 Ngringo, Karanganyar. Intake of research class through random sampling based technique. Activities in data analysis include data processing and statistical analysis. The conclusion of this research is that in general the learning model through interactive learning media (swf video) can motivate students so that they can improve student learning achievement. Students give positive responses to the implementation of interactive learning models (video swf).
\end{abstract}

Keywords: interactive learning, circulatory system, adobe flash, motivation, learning outcomes

Copyright (c) 2020 Udi Budi Harsiwi, Liss Dyah Dewi Arini

$\square$ Corresponding author

Address : Jl. KH. Samanhudi no 93 Sondakan, Laweyan, Surakarta

Email : liss_dyah@udb.ac.id

Phone : :081328322770

ISSN 2580-3735 (Media Cetak)

ISSN 2580-1147 (Media Online)

DOI: https://doi.org/10.31004/basicedu.v4i4.505 
1105 Pengaruh Pembelajaran Menggunakan Media Pembelajaran Interaktif terhadap Hasil Belajar Siswa di Sekolah Dasar- Udi Budi Harsiwi, Liss Dyah Dewi Arini

DOI: https://doi.org/10.31004/basicedu.v4i4.505

\section{PENDAHULUAN}

Salah satu faktor yang mempengaruhi kemajuan bangsa adalah kualitas sumber daya manusia dalam menguasai pengetahuan dan teknologi di era revolusi industri 4.0. Kualitas pendidikan di Indonesia semakin dituntut untuk meningkat agar dapat mengikuti perkembangan zaman yang berkembang dengan sangat pesat. Media pembelajaran adalah salah satu komponen pembelajaran yang sangat penting sebagai jembatan dalam penyampaian materi. Penggunaan media dalam pembelajaran dapat memberikan dampak positif dan manfaat yang sangat luar biasa dalam memudahkan proses belajar siswa. Di samping itu, media pembelajaran merupakan dasar yang sangat diperlukan yang bersifat melengkapi dan merupakan bagian integral demi berhasilnya proses pembelajaran. Berdasarkan penelitian yang dilakukan oleh Kurniawati dan Nita (2018), media pembelajaran berbasis multimedia interaktif telah dinilai layak secara teoritis. Beberapa penelitian sebelumnya menunjukkan bahwa penggunaan multimedia interaktif mampu meningkatkan penguasaan konsep, prestasi belajar, dan kemampuan berpikir kritis. Media merupakan salah satu faktor yang mendukung keberhasilan proses pembelajaran di sekolah karena fungsinya dapat membantu proses penyampaian informasi dari guru kepada siswa ataupun sebaliknya. Karakteristik paling penting pada media pembelajaran interaktif yaitu siswa tidak hanya memperhatikan penyajian atau objek, tetapi juga dipaksa untuk berinteraksi selama mengikuti pelajaran. Permasalahan yang akan diteliti dalam penelitian ini adalah media pembelajaran dalam pelajaran sistem peredaran darah, aktivitas siswa selama proses pembelajaran materi sistem peredaran darah, metode pembelajaran materi sistem peredaran darah yang dilakukan tenaga pengajar dan peran tenaga pengajar selama kegiatan belajar mengajar materi sistem peredaran darah di SDN 06 dan 07 Ngringo. Berdasarkan hasil penelitian Zulhelmi (2017), pengaruh media pembelajaran interaktif dapat meningkatkan Keterampilan berfikir kritis siswa. Tujuan Khusus penelitian ini adalah (1) mengembangkan media pembelajaran berbasis Adobe Flash interaktif; (2) menganalisis perbedaan motivasi antara siswa yang menggunakan media Adobe Flash interaktif dan konvensional; (3) menganalisis perbedaan hasil belajar antara siswa yang menggunakan media Adobe Flash interaktif dan konvensional; (4) menganalisis perbedaan motivasi dan hasil belajar antara siswa yang belajar IPA menggunakan media Adobe Flash interaktif dan konvensional di SD N 06 dan 07 Ngringo, Jaten, Karanganyar. Berdasarkan hasil penelitian disimpulkan bahwa penggunaan media alat peraga dalam pembelajaran menunjukkan pengaruh yang cukup baik terhadap hasil belajar siswa dibandingkan dengan hasil belajar siswa pembelajarannya tidak menggunakan media alat peraga.

Penelitian ini dilakukan untuk menguji pengaruh sistem peredaran darah dan pembelajarannya menggunakan cara cerdas melalui media pembelajaran interaktif di SDN 06 dan 07 Ngringo, Karanganyar dengan harapan memperoleh dan membuktikan suatu persepsi menjadi pengetahuan dan informasi yang dapat 
1106 Pengaruh Pembelajaran Menggunakan Media Pembelajaran Interaktif terhadap Hasil Belajar Siswa di Sekolah Dasar- Udi Budi Harsiwi, Liss Dyah Dewi Arini

DOI: https://doi.org/10.31004/basicedu.v4i4.505

dibuktikan kebenarannya serta dengan tujuan untuk mencapai sasaran pembelajaran secara efektif dan efisien kepada siswa dan siswi SDN 06 dan 07 Ngringo Karanganyar dapat mengerti dan memahami materi sistem predaran darah serta tenaga pengajar memperoleh media dan metode yang tepat untuk meningkatkan pemahaman siswa selama pembelajaran.

\section{METODE}

Penelitian ini menggunakan jenis penelitian eksperimen semu. Hal ini dilihat dari subjek eksperimen yang tidak dirandomisasi untuk menentukan sampel guna ditempatkan dalam kelompok eksperimen dan kelompok kontrol.

Populasi dalam penelitian ini adalah seluruh siswa kelas V SD Negeri 06 dan 07 Ngringo, Jaten, karanganyar yang dikelompokkan dalam dua kelas. Tiap-tiap kelas terdiri dari siswa dengan kemampuan tinggi, sedang sampai rendah.

Pengambilan sampel pada penelitian ini dengan teknik random sampling. Untuk lebih meyakinkan kedua kelompok yang menjadi sampel tidak berbeda secara signifikan, maka diambil nilai tes sumatif. Hasil tes sumatif tersebut kemudian dianalisis dengan uji-t SPSS 16.00 menggunakan Independent Sample's T-Test signifikansi 5\%. Jika angka signifikansi hitung kurang dari 0,05 maka kelas tersebut tidak setara. Sedangkan jika angka signifikansi hitung lebih besar dari 0,05 maka kelas tersebut setara. Dari hasil pengundian diperoleh SD N 07 Ngringo, Jaten, Karanganyar sebagai kelas eksperimen dan SD N 06 Ngringo, Jaten, Karanganyar sebagai kelas kontrol. Variabel bebas dalam penelitian yaitu hasil belajar IPA materi sistem peredaran darah pada manusia. Sedangkan variabel terikat dalam penelitian ini yaitu motivasi dan penggunaan media Adobe Flash interaktif. Data pada penelitian ini ada dua yakni motivasi dan media pembelajaran. Data mengenai motivasi belajar dan penggunaan media pembelajaran dikumpulkan menggunakan kuesioner motivasi skala 5 (skala Likert). Sedangkan data mengenai hasil belajar siswa dikumpulkan dengan menggunakan tes hasil belajar berbentuk essai.

\section{HASIL DAN PEMBAHASAN}

Bagian ini merupakan bagian utama artikel hasil penelitian dan biasanya merupakan bagian terpanjang dari suatu artikel. Hasil penelitian yang disajikan dalam bagian ini adalah hasil "bersih". Proses analisis data seperti perhitungan statistik dan proses pengujian hipotesis tidak perlu disajikan. Hanya hasil analisis dan hasil pengujian hipotesis saja yang perlu dilaporkan. Tabel dan grafik dapat digunakan untuk memperjelas penyajian hasil penelitian secara verbal. Tabel dan grafik harus diberi komentar atau dibahas.

Untuk penelitian kualitatif, bagian hasil memuat bagian-bagian rinci dalam bentuk sub topik yang berkaitan langsung dengan fokus penelitian dan kategori-kategori.

Pembahasan dalam artikel bertujuan untuk: (1) menjawab rumusan masalah dan pertanyaanpertanyaan penelitian; (2) menunjukkan bagaimana temuan-temuan itu diperoleh; (3) menginterpretasi/menafsirkan temuan-temuan; (4) mengaitkan hasil temuan penelitian dengan struktur pengetahuan yang telah mapan; dan (5) 
1107 Pengaruh Pembelajaran Menggunakan Media Pembelajaran Interaktif terhadap Hasil Belajar Siswa di Sekolah Dasar- Udi Budi Harsiwi, Liss Dyah Dewi Arini

DOI: https://doi.org/10.31004/basicedu.v4i4.505

memunculkan teori-teori baru atau modifikasi teori yang telah ada.

Dalam menjawab rumusan masalah dan pertanyaan-pertanyaan penelitian, hasil penelitian harus disimpulkan secara eksplisit. Penafsiran terhadap temuan dilakukan dengan menggunakan logika dan teori-teori yang ada. Temuan berupa kenyataan di lapangan diintegrasikan/ dikaitkan dengan hasil-hasil penelitian sebelumnya atau dengan teori yang sudah ada. Untuk keperluan ini harus ada rujukan. Dalam memunculkan teori-teori baru, teori-teori lama bisa dikonfirmasi atau ditolak, sebagian mungkin perlu memodifikasi teori dari teori lama.

Dalam suatu artikel, kadang-kadang tidak bisa dihindari pengorganisasian penulisan hasil penelitian ke dalam "anak subjudul". Berikut ini adalah cara menuliskan format pengorganisasian tersebut, yang di dalamnya menunjukkan cara penulisan hal-hal khusus yang tidak dapat dipisahkan dari sebuah artikel.

\section{Tampilan Media Pembelajaran Interaktif}

\section{Sistem Peredaran Darah}

Secara umum, ada tiga hasil utama dari penelitian ini. Ketiga hasil penelitian tersebut meliputi : hasil validasi guru IPA, model media pembelajaran interaktif dan analisa data.

a. Hasil validasi media pembelajaran interaktif (video swf) ini dilihat dari instrumen validitas guru IPA. Hasil validitas ini digunakan untuk menentukan kelayakan media pemeblajaran interaktif (video swf) dan pedoman dalam merevisi produk. b. Deskripsi model media pembelajaran interaktif (video swf)

Desain media pembelajaran interaktif (video swf) meliputi : materi, video dan kuis. Tampilan halaman utama dan masing-masing menu di halaman utama media pembelajaran interaktif diperlihatkan pada Gambar 1, 2, 3 dan 4 sebagai berikut :

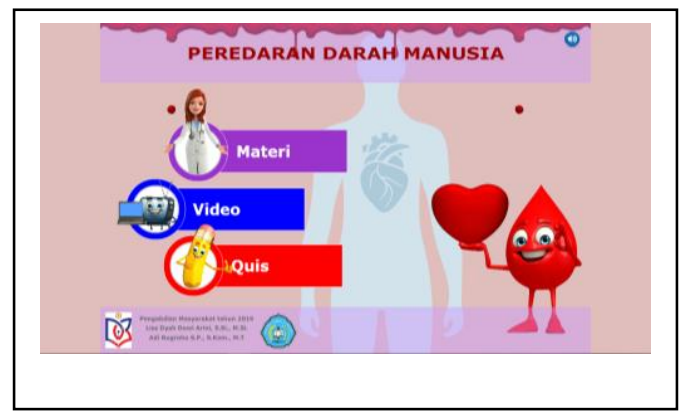

Gambar 1. Tampilan Halaman Utama Media Pembelajaran Interaktif

Halaman utama memberikan gambaran umum berupa berupa menu-menu utama pada media pembelajaran interaktif (video swf) yang terdiri dari menu materi, menu video dan menu kuis. Masing-masing menu tersebut berisi materi-materi pembelajaran peredaran darah manusia, video-video pembelajaran peredaran darah manusia yang mendukung kegiatan belajar mengajar antara guru dan siswa-siswi beserta latihan-latihan soal di menu quis yang dapat dikerjakan dan siswa dapat langsung mengetahui nilainya. 


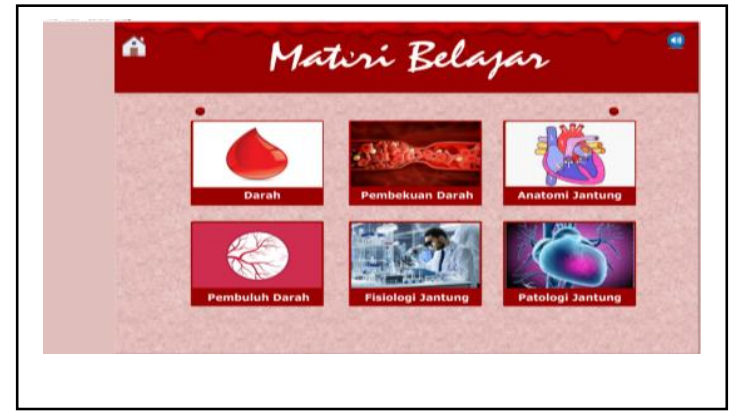

Gambar 2. Menu Pertama di Halaman Utama Media Pembelajaran Interaktif

Menu pertama di halaman utama media pembelajaran interaktif terdiri dari beberapa sub menu, yaitu darah, pembekuan darah, anatomi jantung, pembuluh darah, fisiologi jantung dan patologi jantung. Di mana di masing-masing sub menu ini berisi materimateri terkait darah, pembekuan darah, anatomi jantung, pembuluh darah, fisiologi jantung dan patologi jantung.

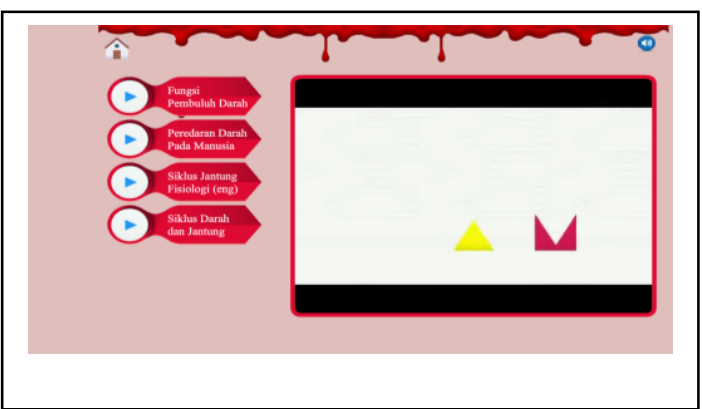

Gambar 3. Menu Kedua di Halaman Utama Media Pembelajaran Interaktif

Menu kedua di halaman utama media pemeblajaran interaktif berisi video-video pembelajaran sistem peredaran darah. Videovideo yang terdapat pada menu kedua di halaman utama media pembelajaran interaktif ini adalah video fungsi pembuluh darah, video peredaran darah pada manusia, video siklus jantung (fisiologi) dan video siklus darah dan jantung.

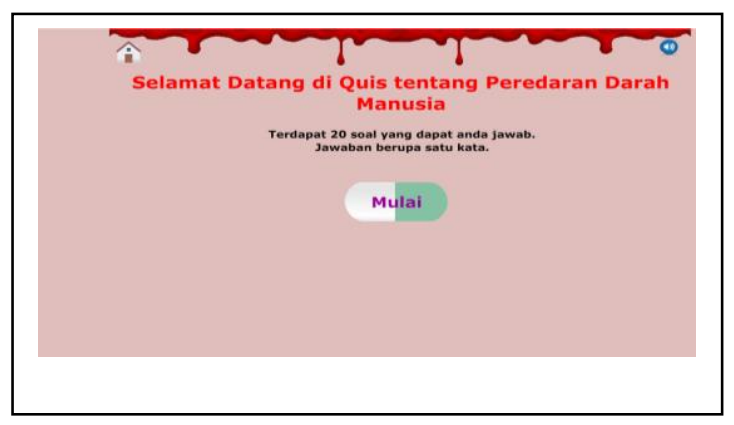

Gambar 4. Menu Ketiga di Halaman Utama Media Pembelajaran Interaktif

Menu ketiga di halaman utama media pembelajaran interaktif ini berupa kuis. Menu kuis ini berisi soal-soal mengenai peredaran darah pada manusia yang berjumlah 20 soal. Soal-soal ini dapat dikerjakan oleh siswasiswi secara mandiri dan mereka dapat langsung mengetahui nilainya.

\section{Hasil Belajar Sampel Dua SD Negeri}

1. Hasil Pre Test dan Post Test SD N 06 Ngringo

Tabel 1. Hasil Pre Test dan Post Test SD N 06 Ngringo

\begin{tabular}{|l|l|c|c|}
\hline \multirow{2}{*}{ No } & \multirow{2}{*}{ Nama } & \multicolumn{2}{|c|}{ Nilai } \\
\cline { 3 - 4 } & & Pre Test & Post Test \\
\hline 1 & Argananta & 100 & 100 \\
\hline 2 & Aurel & 30 & 60 \\
\hline 3 & Adite & 90 & 100 \\
\hline 4 & Queena & 80 & 100 \\
\hline 5 & Rohmat & 60 & 90 \\
\hline 6 & Queena belva & 50 & 90 \\
\hline 7 & Devita & 70 & 100 \\
\hline 8 & Andiena & 30 & 70 \\
\hline 9 & Keisha & 60 & 100 \\
\hline 10 & Safira & 40 & 80 \\
\hline 11 & Thomas & 70 & 100 \\
\hline 12 & Ghozy & 70 & 100 \\
\hline 13 & Ulung & 60 & 90 \\
\hline 14 & Akira & 80 & 100 \\
\hline
\end{tabular}


1109 Pengaruh Pembelajaran Menggunakan Media Pembelajaran Interaktif terhadap Hasil Belajar Siswa di Sekolah Dasar- Udi Budi Harsiwi, Liss Dyah Dewi Arini

DOI: https://doi.org/10.31004/basicedu.v4i4.505

\begin{tabular}{|c|l|c|c|}
\hline 15 & Andrian & 70 & 100 \\
\hline 16 & Yohana & 60 & 90 \\
\hline 17 & Kinarya & 50 & 80 \\
\hline 18 & Kirana & 50 & 90 \\
\hline 19 & Salsabila & 70 & 100 \\
\hline 20 & Florena & 60 & 90 \\
\hline 21 & Aprizal & 40 & 90 \\
\hline 22 & Alfira & 80 & 100 \\
\hline 23 & Febrian & 60 & 100 \\
\hline 24 & Axelian & 80 & 100 \\
\hline 25 & Malika & 50 & 90 \\
\hline 26 & maldini & 80 & 100 \\
\hline
\end{tabular}

\section{Gambar 5. Hasil Pre Test dan Post Test SD N 06 Ngringo}

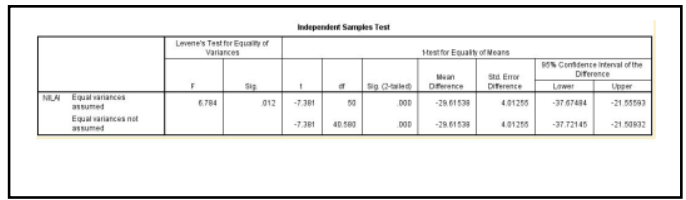

Gambar 6. Hasil Pre Test dan Post Test SD N 06 Ngringo

2. Hasil Pre Test dan Post Test SD N 07 Ngringo

Tabel 2. Hasil Pre Test dan Post Test SD N 07 Ngringo

\begin{tabular}{|l|l|c|c|}
\hline \multirow{2}{*}{ No } & \multicolumn{1}{|c|}{ Nama } & \multicolumn{2}{|c|}{ Nilai } \\
\cline { 2 - 4 } & & Pre Test & Post Test \\
\hline 1 & Cindi & 70 & 100 \\
\hline 2 & Fitri & 60 & 100 \\
\hline 3 & Kintan & 80 & 100 \\
\hline 4 & Puri & 10 & 70 \\
\hline 5 & Sukma & 70 & 100 \\
\hline 6 & Nisa & 70 & 100 \\
\hline 7 & Eni & 90 & 100 \\
\hline 8 & Naomi & 60 & 90 \\
\hline 9 & Mila & 90 & 100 \\
\hline 10 & Fauziah & 90 & 100 \\
\hline 11 & Nugroho & 60 & 90 \\
\hline 12 & Indah & 70 & 100 \\
\hline 13 & Artiza & 80 & 100 \\
\hline 14 & Putri & 60 & 90 \\
\hline 15 & Mela & 80 & 100 \\
\hline 16 & Feri & 70 & 100 \\
\hline
\end{tabular}

\section{Penentuan Sampel Dua SD Negeri}

Nilai pre test dan post test dari siswa kedua SD yaitu SD Negeri 06 Ngringo dan SD Negeri 07 Ngringo selanjutnya dilakukan analisa komparatif untuk menunjukkan bahwa kedua sampel sekolah tersebut mempunyai taraf hasil belajar yang sama.

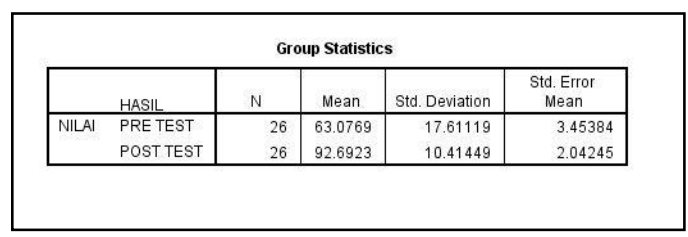

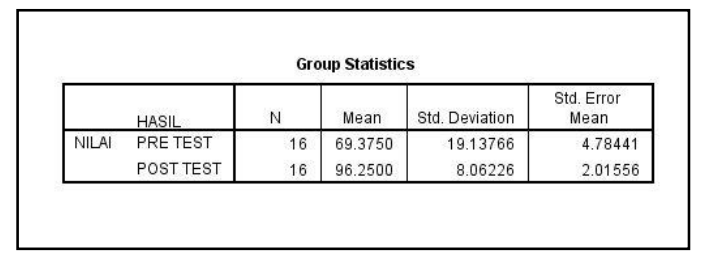

Gambar 7. Hasil Pre Test dan Post Test SD N 07 Ngringo

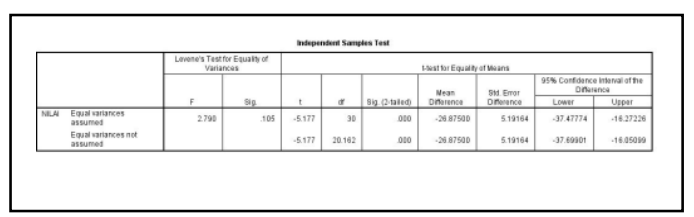

Gambar 8. Hasil Pre Test dan Post Test SD N 07 Ngringo

Dari kedua tabel statistika diatas menunjukan bahwa keduanya mempunyai sampel yang berbeda. Pada SD N 6 Ngrigo mempunyai 26 sampel, dari hasil data di temukan bahwa nilai post test lebih tinggi dibanding nilai pre test dilihat dari rata-rata 92,69 > 63,08. Sedangkan pada SD N 7 Ngrigo mempunyai 16 sampel, dari hasil data ditemukan bahwa nilai post test jauh lebih tinggi daripada nilai pre test dilihat dari rata-rata 96,25 > 69,38. Jadi dapat disimpulkan bahwa kedua tabel tersebut memiliki hasil rata-rata nilai yang cenderung lebih tinggi pada post test. Dari kedua tabel independent menunjukan bahwa pada SD N 6 Ngrigo dan SD $\mathrm{N} \quad 7 \quad$ Ngrigo terlihat nilai signifikansi 2-tailed $0.000<0.05$, maka $\mathrm{H}_{0}$ ditolak 
1110 Pengaruh Pembelajaran Menggunakan Media Pembelajaran Interaktif terhadap Hasil Belajar Siswa di Sekolah Dasar- Udi Budi Harsiwi, Liss Dyah Dewi Arini

DOI: https://doi.org/10.31004/basicedu.v4i4.505

dan di terima $\mathrm{H}_{\mathrm{a}}$. Sehingga dapat disimpulkan bahwa kedua SD tersebut mempunyai taraf belajar yang sama.

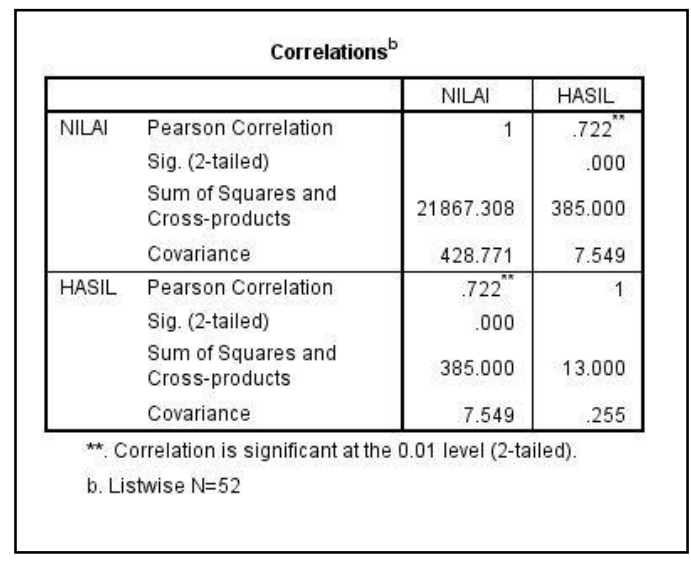

Gambar 9. Hasil pre test dan post test SD N 6 Ngringo

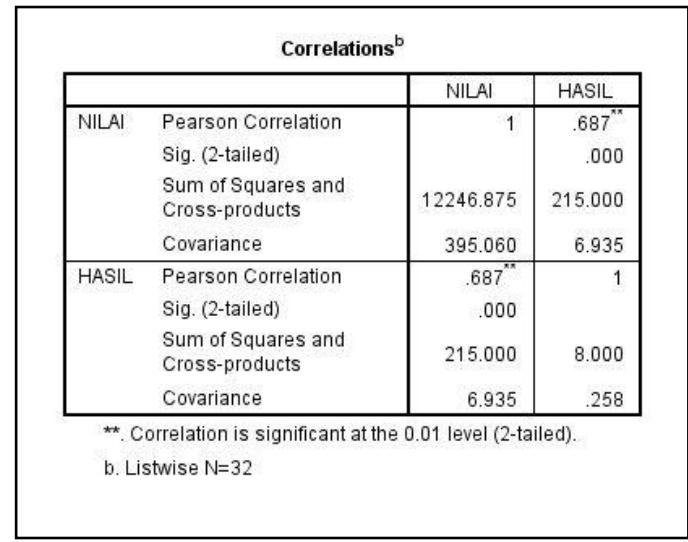

Gambar 10. Hasil pre test dan post test SD N 7 Ngringo

Berdasarkan kedua tabel diatas diketahui jika kedua nilai signifikansi Sig. (2-tailed) antara nilai dengan hasil adalah $0,00<0,05$ yang artinya terdapat korelasi yang signifikan antara variabel nilai dan variabel hasil.

Diketahui juga nilai r-hitung (Pearson Correlations) untuk hubungan nilai dan hasil pada SDN 6 adalah sebesar 0,722 < r tabel 1,sedangkan pada SDN 7 adalah sebesar $0,687<$ r-tabel 2 .
Maka dapat disimpulkan bahwa keduanya memiliki hubungan atau korelasi antara variabel nilai dengan variabel hasil. Karena r-hitung atau Pearson Correlations dalam analisis ini bernilai positif maka artinya hubungan antara kedua variabel tersebut bersifat positif. Jadi kedua tabel menunjukan hasil nilai $\mathrm{r}$ hitung serta nilai signifikansi yang sama bearti kedua SD mempunyai taraf belajar yang sama.

Hasil penelitian ini memiliki kemiripan dengan penelitian (Prasetya, 2011) yang mengatakan bahwa terdapat perbedaan (t-hitung $(2,90)>\mathrm{t}$-tabel $(1,99))$ prestasi belajar antara siswa yang belajar menggunakan multimedia pembelajaran interaktif dengan siswa yang belajar menggunakan modul, yaitu prestasi belajar menggunakan multimedia interaktif lebih baik dibandingkan dengan pembelajaran menggunakan modul. Rahayu (2017) juga mengatakan bahwa hasil perhitungam uji $\mathrm{t}$ didapatkan $\mathrm{t}=2,089 ; \mathrm{F}=$ 15,285 dan signifikansi 2-tail 0,40/0,41 lebih kecil dari signifikansi 0,05, maka $\mathrm{H}_{0}$ ditolak dan $\mathrm{H}_{\mathrm{a}}$ diterima. Artinya, ada perbedaan yang signifikan pada penggunaan multimedia pembelajaran interaktif terhadap hasil belajar siswa di SDN Gadang 01 Malang. Doreng, dkk (2016) juga mengatakan bahwa penggunaan multimedia interaktif model tutorial membantu meningkatkan kemampuan siswa menjadi lebih baik dibandingkan dengan media handout dengan ratarata prestasi siswa yang belajar menggunakan media handout mendapatkan nilai $\mathrm{N}$-gain sebesar 0,51 (sedang). Rata-rata prestasi siswa yang belajar menggunakan multimedia interaktif model tutorial mendapat nilai $N$-gain sebesar 0,54 
1111 Pengaruh Pembelajaran Menggunakan Media Pembelajaran Interaktif terhadap Hasil Belajar Siswa di Sekolah Dasar- Udi Budi Harsiwi, Liss Dyah Dewi Arini

DOI: https://doi.org/10.31004/basicedu.v4i4.505

(sedang). Kesimpulan dari penelitian ini adalah multimedia interaktif dapat meningkatkan hasil belajar siswa lebih baik dari pada media handout.

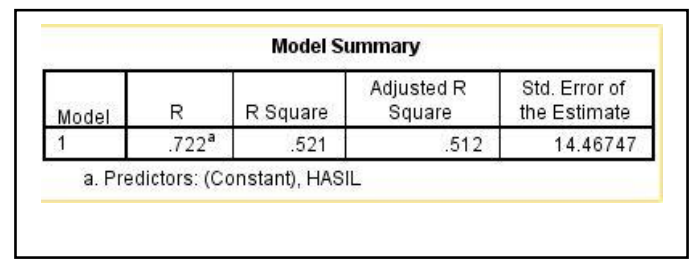

Gambar 11. Hasil pre test dan post test SD N 6 Ngringo

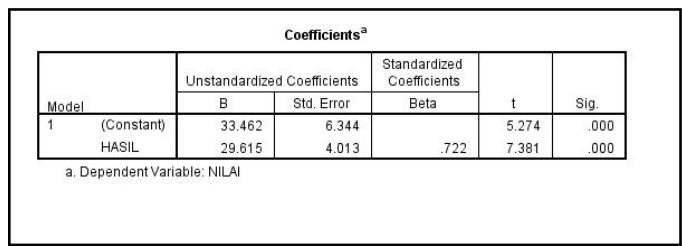

Gambar 12. Hasil pre test dan post test SD N 6 Ngringo

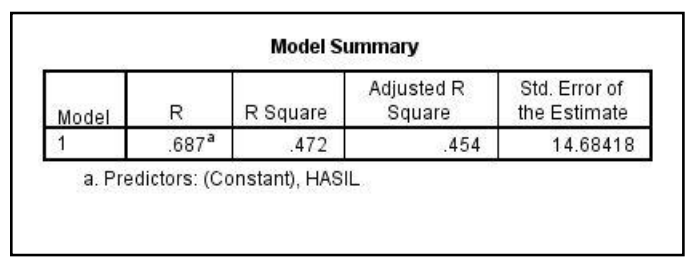

Gambar 13. Hasil pre test dan post test SD N 7 Ngringo

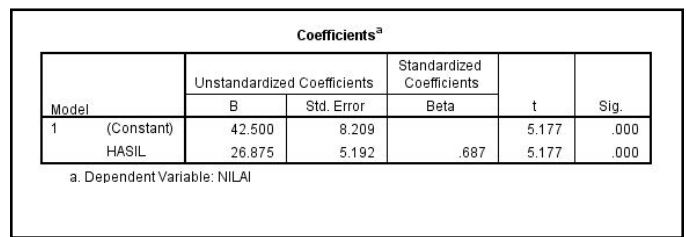

Gambar 14. Hasil pre test dan post test SD N 7 Ngringo

\section{SIMPULAN}

Berdasar hasil penelitian, maka dapat disimpulkan sebagai berikut :

1. Secara umum model pembelajaran melalui media pembelajaran interaktif (video swf) dapat memotivasi siswa sehingga dapat meningkatkan prestasi belajar mahasiswa.

2. Siswa memberikan respon positif terhadap implementasi model pembelajaran interaktif (video swf).

\section{UCAPAN TERIMA KASIH}

Penulis mengucapkan terima kasih kepada Kemenristekdikti/BRIN yang telah mendanai penelitian ini melalui hibah pendanaan tahun 2019 dengan no kontrak : 024/UDB.LPPM/A.34HK/III/2020.

\section{DAFTAR PUSTAKA}

Anam, Khoirul. 2015. “Terdapat pengaruh penggunaan media pembelajaran terhadap minat belajar siswa pada mata pelajaran PAI di SMP Bani Muqiman Bangkalan". Jurnal Pendidikan Islam/Vol. 4, No. 2.

Soimah, Ika. 2018. "Pengaruh Media Pembelajaran Berbasis Komputer Terhadap Hasil Belajar IPA Ditinjau Dari Motivasi Belajar Siswa”. Jurnal Ilmiah Pendidikan IPA, Volume 5 No 1.

Viviantini, Rede, Amran dan Saehana, Sahrul. 2015. "Pengaruh Media Video Pembelajaran Terhadap Minat Dan Hasil Belajar IPA Siswa Kelas VI SDN 6 Kayumalue Ngapa". Jurnal Sains dan Teknologi Tadulako, Volume 4 Nomor 1.

Oetomo, Budi Sutedjo Darma. (2007). Eeducation: Konsep Teknologi dan Aplikasi Internet Pendidikan. Yogyakarta: Andi Offset.

Daryanto. (2011). Media Pembelajaran. Bandung: Sarana Tutorial Nurani Sejahtera.

Indriana, Dina. (2011). Ragam Alat Bantu Media Pengajaran. Yogyakarta: Diva Press.

Rafika, Elma dan Asrizal. 2014. Pembuatan Lembar Kerja Siswa IPA Terpadu 
1112 Pengaruh Pembelajaran Menggunakan Media Pembelajaran Interaktif terhadap Hasil Belajar Siswa di Sekolah Dasar- Udi Budi Harsiwi, Liss Dyah Dewi Arini

DOI: https://doi.org/10.31004/basicedu.v4i4.505

Berbasis ICT Mengintegrasikan Nilai Pendidikan Karakter Untuk Pembelajaran IPA siswa SMP Kelas VIII. Jurnal EKSAKTA Volume I Tahun XV Februari 2014 h.81-91. Universitas Negeri Padang.

Carey, G. 2010. Integrated Metabolism: An Interactive Learning Tool for Nutrition, Biochemistry, and Physiology. Journal of College Science Teaching, 39(4): 1622.

Kurniawati, I.D dan Nita, S. 2018. "Media Pembelajaran Berbasis Multimedia Interaktif untuk Meningkatkan Pemahaman Konsep Mahasiswa". Journal of Computer and Information Technology Vol.1, No. 2.

Ferawati. 2011. "Model Pembelajaran Multimedia Interaktif untuk Meningkatkan Penguasaan Konsep dan Keterampilan Generik Sains Guru Fisika pada Topik Fluida Dinamis". Proseding Penelitian Bidang Ilmu Eksakta 2011, (2011),hal: 1-10.

Prastika, L. R., dkk. 2015. "Pengaruh Penggunaan Multimedia Interaktif Berbasis Komputer Model Instructional Games terhadap Peningkatan Prestasi Belajar Siswa pada Mata Pelajaran Fisika". Prosiding Simposium Nasional Inovasi Pembelajaran dan Sains 2011 (SNIPS 2015) Bandung, (2015): hlm 397-400.

Wiyono, K., dkk. 2009. "Model Pembelajaran multimedia Interaktif Relativitas Khusus untuk Meningkatkan Keterampilan Berpikir Kritis Siswa SMA". Makalah Seminar Nasional Pendidikan di FKIP Universitas Sriwijaya Palembang, (2009): hal: $1-12$.

Arda dan Darsikin. 2015. "Pengembangan Media Pembelajaran Interaktif Berbasis Komputer Untuk Siswa Smp Kelas VIII". e-Jurnal Mitra Sains, Volume 3 Nomor 1.

Tarigan, D Dan Siagian, S. 2015. "Pengembangan Media Pembelajaran Interaktif Pada Pembelajaran Ekonomi”. Jurnal Teknologi Informasi \& Komunikasi Dalam Pendidikan, Vol. 2, No. 2.
Zulhelmi, Adlim dan Mahidin. 2017. "Pengaruh Media Pembelajaran Interaktif Terhadap Peningkatkan Keterampilan Berpikir Kritis Siswa". Jurnal Pendidikan Sains Indonesia, Vol. 05, No.01.

Qosyim, A dan Proyonggo, F.V. 2017. "Penerapan Media Pembelajaran Interaktif Menggunakan Flash Untuk Materi Sistem Gerak Pada Manusia Kelas VIII". Jurnal Penelitian Pendidikan IPA Vol.2 No.2.

Pohan, A.B dan Jaelani, N.R. 2018. "Pengembangan Media Pembelajaran Interaktif Pelajaran Matematika Mengenal Bangun Ruang Dengan Metode Inkuiri Untuk Siswa Tingkat Dasar". Jurnal Khatulistiwa Informatika, Vol. VI, No. 1.

Kuswanto, J dan Radiansah, F. 2018. "Media Pembelajaran Berbasis Android Pada Mata Pelajaran Sistem Operasi Jaringan Kelas XI”. Jurnal Media Infotama Vol. 14 No. 1.

Saselah, Y.R, Amir, M dan Qadar, R. 2017. "Pengembangan Multimedia Interaktif Berbasis Adobe Flash Cs6 Professional Pada Pembelajaran Kesetimbangan Kimia". JKPK (Jurnal Kimia Dan Pendidikan Kimia), Vol. 2, No. 2.

Auliya, N.N.F. "Pengembangan Pembelajaran Berbasis Multimedia Interaktif Menggunakan Adobe Flash Cs.6 dalam Pembelajaran Matematika Pada Kelas $\mathrm{X}$ Materi Pokok Pertidaksamaan Satu Variabel”. Jurnal Pendidikan Matematika Vol 1 No 1.

Supriyadi. 2016. "Adobe Flash Untuk Mendukung Pembelajaran". Jurnal Komunikasi, Volume VII Nomor 2.

Yuzarion. 2017. "Faktor Yang Mempengaruhi Prestasi Belajar Peserta Didik". Jurnal Ilmu Pendidikan, Volume 2 Nomor 1.

Rusmiati. 2017. "Pengaruh Minat Belajar Terhadap Prestasi Belajar Bidang Studi Ekonomi Siswa Ma Al Fattah Sumbermulyo". Jurnal Ilmiah 
1113 Pengaruh Pembelajaran Menggunakan Media Pembelajaran Interaktif terhadap Hasil Belajar Siswa di Sekolah Dasar- Udi Budi Harsiwi, Liss Dyah Dewi Arini

DOI: https://doi.org/10.31004/basicedu.v4i4.505

Pendidikan Dan Ekonomi Volume 1, No. 1.

Siagian, R.E.F. 2017. "Pengaruh Minat Dan Kebiasaan Belajar Siswa Terrhadap Prestasi Belajar Matematika". Jurnal Formatif 2 (2).

Aisyah, N, Widiyanto, B dan Fatkhurrohman, M.A. 2018. "Efektivitas Penggunaan Alat Peraga Sistem Peredaran Darah terhadap Hasil Belajar Peserta Didik Kelas VII SMP N 12 Kota Tegal". Jurnal Pendidikan MIPA Pancasakti JPMP Volume 2 Nomor 1.

Prasetya, D. 2011. "Interaktif Dan Modul Pembelajaran Terhadap Prestasi Belajar Siswa Kelas 3 Pada Pembelajaran Automatic Main Failure (Amf) Power System Di SMK Negeri 3 Yogyakarta". Skripsi. Yogyakarta : UNY.

Rahayu., S dan Farida, N. 2017. "Perbedaan Pembelajaran Melalui Multimedia Interaktif dan Melalui Buku Teks Terhadap Hasil Belajar Siswa pada Materi Pecahan Kelas IV SDN Gadang 01 Malang". JIP Vol 7 No 1hal 7-12.

Doreng, R; Wiharna, O dan Kumaro, M. 2016. "Perbandingan Hasil Belajar Multimedia Interaktif Model Tutorial Dengan Media Handout Pada Kompetensi Gambar Teknik". Journal of Mechanical Engineering Education Vol 3 No 2. 